Eosinophils are present throughout the airway wall of asthmatics. The nature of the interaction between human airway smooth muscle cells (ASMC) and eosinophils was investigated in this study. We demonstrated, using light microscopy, that freshly isolated eosinophils from healthy donors rapidly attach to ASMC in vitro. Numbers of attached eosinophils were highest at $2 \mathrm{~h}$, falling to $50 \%$ of maximum by $20 \mathrm{~h}$. Eosinophil attachment at $2 \mathrm{~h}$ was reduced to $72 \%$ of control by anti-VCAM-1, and to $74 \%$ at $20 \mathrm{~h}$ by antiICAM-1. Pre-treatment of ASMC for $24 \mathrm{~h}$ with TNF- $\alpha$, $10 \mathrm{nM}$, significantly increased eosinophil adhesion to 149 and $157 \%$ of control after 2 and $20 \mathrm{~h}$. These results provide evidence that eosinophil in teractions with ASMC involve VCAM-1 and ICAM-1 and are modulated by TNF- $\alpha$.

Key words: Asthma, Eosinophils, Airway smooth muscle, ICAM-1, VCAM-1, TNF- $\alpha$, IL-1 $\beta$, IL-5

\section{Human eosinophil-airway smooth muscle cell interactions}

\author{
J. Margaret Hughes ${ }^{1, C A}$, Craig A. Arthur ${ }^{1}$, \\ Shane Baracho', Stephen M. Carlin², \\ Kristen M. Hawker ${ }^{2}$, Peter R.A. Johnson ${ }^{2}$ and \\ Carol L. Armour ${ }^{1}$
}

Respiratory Research Group, Faculty of Pharmacy ${ }^{1}$ and Department of Pharmacology ${ }^{2}$, University of Sydney, Sydney, NSW 2006, Australia

\author{
${ }^{\mathrm{CA}}$ Corresponding Author \\ Tel: 61-2-93514434 \\ Fax: 61-2-93514391 \\ E-mail: margh@pharm.usyd.edu.au
}

\section{Introduction}

Asthmatic airways are hyperresponsive, contain an increased amount of airway smooth muscle and are infiltrated by a varie ty of inflammatory cells, including eosinophils and T-lymphocytes. It is now widely accepted that both the increased smooth muscle bulk and inflammatory cell products contribute to airway hyperresponsiveness. There is growing evidence that inflammatory cell products not only alter the contractility of airway smooth muscle cells (ASMC) but also their adhesion molecule expression, proliferation and mediator secretion. ${ }^{1-4}$

Many groups have demonstrated that eosinophil numbers and levels of their secreted granule proteins, both in airw ay fluid and in peripheral blood, correlate with asthma severity. Eosinophil densities in the lumen reflect those in the inner airway wall in fatal asthma. ${ }^{5}$ Cytokines such as interleukin(IL)-5, produced mainly by T-lymphocytes, promote eosinophil recruitment, activation and survival in airw ay tissues. ${ }^{6}$ Once activated, eosinophils are a source of a wide range of mediators, many of which are implicated in altering airway smooth muscle function. They release the potent smooth muscle constrictors leukotrienes $\mathrm{C}_{4}, \mathrm{D}_{4}$ and $\mathrm{E}_{4}$. The first direct link between eosinophils and the induction of airway hyperresponsiveness was established when we demonstrated that supernatants from activated eosinophils increase the contractile responses of human bronchial rings to histamine in vitro. ${ }^{7}$ One eosinophil product known to induce such in vitro hyperresponsiveness is $\mathrm{PAF}^{8}$ However, eosinophils also release a variety of grow th factors and cytokines known to modulate other functions of ASMC. These include the cytokines tumour necrosis factor- $\alpha$ (TNF- $\alpha$ ) and IL- $1 \beta$, which are present in increased amounts in the airway fluid of asth matics.

TNF- $\alpha$ and IL- $1 \beta$ have a variety of effects on ASMC. They modulate ASMC proliferation ${ }^{9,10}$ and increase ASMC adhesion molecule expression. ${ }^{1}$ More recently TNF- $\alpha$ and IL-1 $\beta$ have also been shown to induce ASMC to release cytokines and chemokines, including eotaxin and granulocyte-microphage colony stimulating factor (GM-CSF), implicated in the recruitment and survival of eosinophils. ${ }^{11,12}$

Since eosinophils release products that induce a variety of changes in airway smooth muscle and they are found in this smooth muscle layer, the nature of the interaction between these two cell-types needs to be investigated. In this study we investigated the adhesion of human eosinophils to human ASMC in culture. The adhesion molecules involved and the effects of the cytokines TNF- $\alpha$, IL-1 $\beta$ and IL- 5 on this adhesion were studied.

\section{Materials and methods}

\section{Materials}

All cell culture requirements were obtained from Trace Biosciences (Sydney, Australia) except for 
DMEM, penicillin, streptomycin, amphotericin B which were supplied by Gibco BRL (Life Technologies, Melbourne, Australia). Antibodies to ICAM-1 (clone LB-2, Camfolio and HA58, PharMingen International), VCAM-1 (E1/6, Camfolio and 51-10C9, PharMingen International) and irrelevant antibodies of the same isotypes were supplied by Becton Dickinson (Sydney, Australia) in PBS with $\leq 0.09 \%$ $\mathrm{NaN}_{3}$ and were diluted just prior to use in RPMI-1640. Recombinant human TNF- $\alpha$ and IL-I $\beta$ we re supplied by R\&D Systems Inc (Minneapolis, MN, USA), reconstituted in PBS with $0.1 \% \mathrm{w} / \mathrm{v}$ bovine serum albumin (BSA; Sigma-Aldrich, Australia) at $10 \mu \mathrm{g} / \mathrm{ml}$ and aliquots stored at $-20^{\circ} \mathrm{C}$. Recombinant human IL-5 was obtained from PharMingen International (San Diego, CA, USA), aliquots were stored at $-70^{\circ} \mathrm{C}$ at $50 \mathrm{ng} / \mu \mathrm{l}$ in PBS with $0.1 \%$ BSA. All three cytokines were diluted immediately before use in RPMI-1640.

\section{Human airway smooth muscle cell isolation and culture}

Human lung was obtained from patients undergoing either surgical resection or lung transplantation. Human airway smooth muscle cells were prepared as described previously by Hawker et al. ${ }^{3}$ Briefly, smooth muscle bundles (explants) were dissected out of bronchial segments, washed thoroughly and transferred to culture flasks in DMEM supplemented with $10 \%$ FBS, L-glutamine $(4 \mathrm{mM})$ and antibiotics (penicillin $20 \mathrm{U} / \mathrm{l}$, streptomycin $20 \mu \mathrm{g} / \mathrm{ml}$ and amphotericin $\mathrm{B} \quad 2.5 \mu \mathrm{g} / \mathrm{ml}$ ) and maintained at $37^{\circ} \mathrm{C}$ in a humidified $5 \% \mathrm{CO}_{2}$ in air atmosphere. Medium was changed every 5 days until the airw ay smooth muscle cells (ASMC) grew to confluence, when they were passaged using trypsin-EDTA. ASMC at passages 3-7 were used in the experiments described below.

Prior to commencement of experiments the medium on confluent ASMC was changed to RPMI1640 supplemented with $10 \%(\mathrm{v} / \mathrm{v})$ heat-inactivated FBS, Hepes $2 \mathrm{mM}$, L-glutamine $2 \mathrm{mM}$ and gentamycin $20 \mu \mathrm{g} / \mathrm{ml}$ (RPMI) for at least $24 \mathrm{~h}$ prior to harvest. The ASMC were then harvested using trypsin-EDTA, washed thoroughly and plated into 4-well slide-wells at $1.5-2.5 \times 10^{5}$ cells $/ \mathrm{well}$ in $0.5 \mathrm{ml} \mathrm{RPMI}$ and cultured for 2 days prior to the addition of eosinophils.

\section{Eosinophil isolation}

Eosinophils were isolated from $60-120 \mathrm{ml}$ heparinized peripheral blood collected from healthy volunteers using modifications of the methods of Hansel and colleagues. ${ }^{13}$ Briefly, the blood was mixed 5:1 with $6 \%(\mathrm{w} / \mathrm{v})$ high molecular weight dextran in normal saline and the red cells allowed to sediment for $40 \mathrm{~min}$ at room temperature. The leucocyteenriched fraction was collected and underlayered with percoll $\delta 1.088 \mathrm{~g} / \mathrm{ml}$ and spun at $700 \times g$ for $20 \mathrm{~min}$ at room temperature. Leucocytes at the bottom of the gradient immediately above and in the red cell pellet, were collected and the red cells lysed with $5 \times$ the collected cell volume of lysis buffer $\left(0.82 \% \mathrm{w} / \mathrm{v} \mathrm{NH} \mathrm{NH}_{4} \mathrm{Cl}, 0.1 \% \mathrm{w} / \mathrm{v} \mathrm{K}_{2} \mathrm{CO}_{3}, 0.1 \mathrm{mM}\right.$ EDTA) for $15 \mathrm{~min}$ at $4^{\circ} \mathrm{C}$. The remaining leucocytes were washed thoroughly, incubated with magnetic microbeads coated with antibody to CD16 for 30 min at $6^{\circ} \mathrm{C}$ and cells expressing CD16 (neutrophils) removed using a MACS cell separator. With this method eosinophils were isolated to $\geq 95 \%$ purity and with $\geq 98 \%$ viability as assessed by Kimura Light staining and trypan blue exclusion, respectively. The eosinophils were then immediately washed $2 \times$ with sterile RPMI and added to the ASMC in slide-wells at $1.5-2.5 \times 10^{5}$ eosinophils/well and co-cultured at $37^{\circ} \mathrm{C}$ in a humidified $5 \% \mathrm{CO}_{2}$ in air atmosphere for up to $20 \mathrm{~h}$ as detailed below.

\section{Slide-well processing and assessment of eosinophil adhesion}

At the appropriate harvest time the slide-wells were gently rocked and all the culture medium removed from each well. The cell layer in the wells was then gently washed $3 \times$ with RPMI, drained, fixed in $100 \%$ methanol and air-dried. The cells still adhering to the bottom of the slide-well were stained with KimuraLight and the number of eosinophils attached to the ASMC layer counted in 20 fields of view (10 fields across and 10 fields down) in each well using light microscopy and $200 \times$ magnification.

\section{Time course}

In order to determine the temporal pattern of eosinophil adhesion to ASMC, eosinophils were added to ASMC in slide-wells and duplicate slide-wells processed immediately or after $0.5,1,2,4,8,16$ and $20 \mathrm{~h}$ of co-culture.

\section{Adhesion molecule identification}

The role of the adhesion molecules ICAM-1 and VCAM-1 on eosinophil adhesion to ASMC was determined by incubating ASMC in duplicate slide-wells with antibodies $(1.0,3.0$ or $10.0 \mu \mathrm{g} / \mathrm{ml})$ to either ICAM-1, VCAM-1 or irrelevant antibodies of the same isotype, for $30 \mathrm{~min}$ at $37^{\circ} \mathrm{C}$ prior to the addition of the eosinophils. The slide-wells were then processed after 2 or 20 h of co-culture.

\section{Effect of cytokines}

$I L-1 \beta$ and TNF- $\alpha$.

The effects of the cytokines IL-1 $\beta(0.1,1.0$ and $10 \mathrm{nM})$ and TNF- $\alpha(0.1,1.0$ and $10 \mathrm{nM})$, alone and in 
combination, on eosinophil adhesion to ASMC were examined by adding the cytokines, or their vehicle, to duplicate slide-wells containing the ASMC $24 \mathrm{~h}$ before or at the same time as the eosinophils. The eosinophils were co-cultured with the ASMC, in the presence of the cytokines, for 2 or $20 \mathrm{~h}$ and then the slidewells were processed. As a result of these treatment protocols the ASMC were treated with cytokine for a total of 2 or $26 \mathrm{~h}$ when the eosinophils were present for only $2 \mathrm{~h}$ and for 20 or $44 \mathrm{~h}$ when the eosinophils were present for $20 \mathrm{~h}$.

\section{IL-5.}

The effect of IL-5 on eosinophil adhesion to ASMC w as examined by adding the IL-5 ( 10 and $100 \mathrm{ng} / \mathrm{ml}$ ), or its vehicle, to duplicate slide-wells containing ASMC when the eosinophils were added. The cells were cocultured in the presence of the IL-5 for 2 or $20 \mathrm{~h}$ and then the slide-wells were processed as described earlier.

The combined effect of IL- 5 and TNF- $\alpha$ on eosinophil adhesion to ASMC was also examined. ASMC in duplicate slide-wells were pre-treated with TNF- $\alpha$ $(10 \mathrm{nM})$ for $24 \mathrm{~h}$ prior to the addition of the eosinophils and IL-5 (10 and $100 \mathrm{ng} / \mathrm{ml})$. After $2 \mathrm{~h}$ of coculture in the presence of both the TNF- $\alpha$ and IL- 5 , the slide wells were processed (ASMC TNF- $\alpha$ exposure $=26 \mathrm{~h}$ ).

\section{Data analysis}

The counts ( 2 counts of 10 fields each per well) of eosinophils attached to ASMC per 10 fields of view for the duplicate wells receiving each treatment were averaged. The number of eosinophils attached to ASMC were standardised in each experiment. For the time course experiments the data for each experiment were expressed as a percentage of the maximum number of eosinophils attached to ASMC per 10 fields of view. In the remaining experiments the data for each experiment were expressed as a percentage of the untreated control.

For each series of experiments ASMC established from bronchial tissue obtained from 3-9 different patients were used together $w$ ith eosinophils isolated from 3-9 different healthy volunteer donors. The percentage of eosinophils attached was averaged and the standard error calculated for each time point/ treatment. Analyses were performed on this mean data and significance $(p \leq 0.05)$ determined with ANOVA and Fisher's (PLSD) test.

\section{Ethical approval}

Lung samples were used with the informed consent of each patient and with the approval of the relevant Area Health Service or Hospital Ethics Committee. Blood was collected from healthy volunteer donors

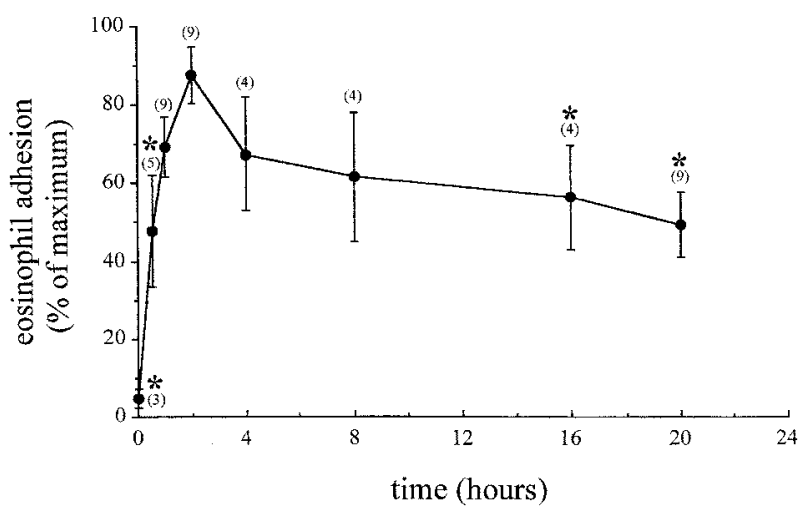

FIG. 1. Eosinophil adhesion to airway smooth muscle cells after various periods of co-culture. Values are means $\pm \mathrm{SE}$; (n), number of experiments; ${ }^{*}$, significantly different from $2 \mathrm{~h}$.

with their informed consent. Ethical approval for these experiments was granted by the University of Sydney Human Ethics Committee.

\section{Results}

\section{Time course}

Eosinophils adhered rapidly to ASMC, with maximum numbers being observed in most experiments by $2 \mathrm{~h}$ of co-culture. The numbers of attached eosinophils then declined to $49.4 \pm 8.9 \%$ of maximum by $20 \mathrm{~h}$ (Fig. 1).

\section{Adhesion molecule identification}

Antibodies to the adhesion molecules ICAM-1 and VCAM-1 reduced eosinophil attachment to ASMC. Pretreatment of ASMC with anti-ICAM-1 ( 3 and $10 \mu \mathrm{g} / \mathrm{ml})$ for $30 \mathrm{~min}$ prior to and during a $20 \mathrm{~h}$ co-culture period with eosinophils significantly $(p<0.05, n=4)$ reduced eosinophil attachment to the ASMC to $77.0 \pm 3.3 \%$ and $74.3 \pm 5.0 \%$ of the untreated control respectively (Fig. 2a), whereas anti-VCAM-1 had no effect (Fig. 2b). With a shorter $2 \mathrm{~h}$ co-culture period, there was more variability in eosinophil attachment, particularly in the presence of anti-ICAM-1 and the isotype control antibody (Fig. 2c). Anti-ICAM-1 $(3 \mu \mathrm{g} / \mathrm{ml})$ had no significant effect but anti-VCAM- $1(3 \mu \mathrm{g} / \mathrm{ml})$ did significantly $(p<0.05, n=4)$ reduce eosinophil attachment to ASMC $(71.7 \pm 4.2 \%$ of the untreated control) compared with the isotype control $(118.6 \pm 16.6 \%$ of the untreated control) (Fig. 2c).

\section{Effects of cytokines}

IL-1 $\beta$ and TNF- $\alpha$.

IL-1 $\beta$ had a small effect on eosinophil attachment to ASMC, $10 \mathrm{nM}$ IL-1 $\beta$ reduced eosinophil attachment significantly to $81.1 \pm 8.2 \%$ of the untreated control compared with $92.8 \pm 0.8 \%$ in the vehicle control 
a)

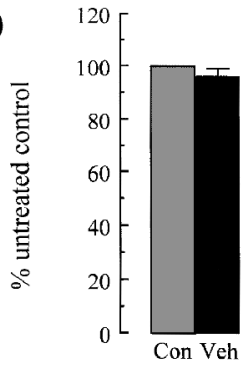

b)

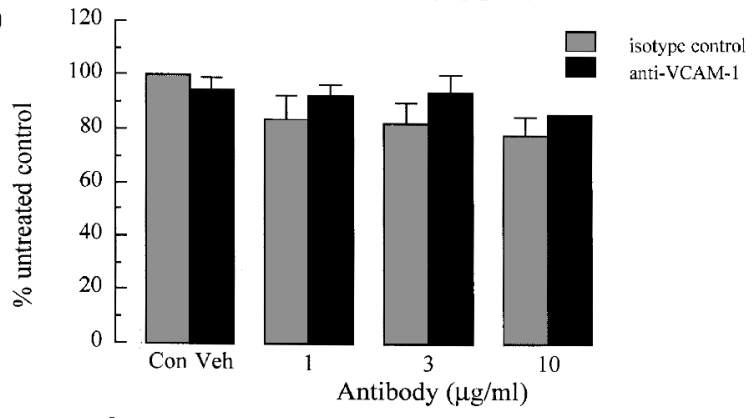

c)

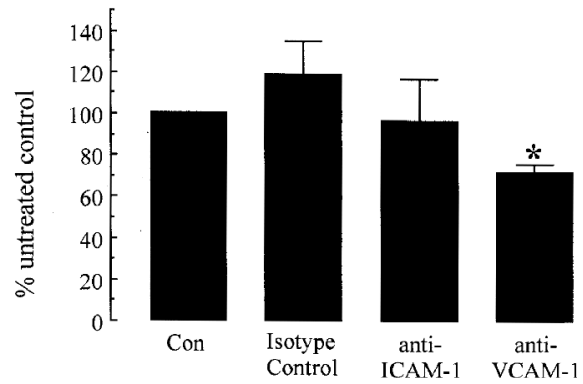

FIG. 2. Eosinophil adhesion to airway smooth muscle cells in the presence of antibodies to the adhesion molecules: (a) ICAM-1 (mouse IgG2b, clone LB-2), and (b) VCAM-1 (mouse $\lg \mathrm{G} 1$, clone $\mathrm{E} 1 / 6$ ) for $20 \mathrm{~h}$ of co-culture, or (c) ICAM-1 (mouse IgG1, cloneHA58) and VCAM-1 (mouse IgG1, clone51-10C9) for $2 \mathrm{~h}$ of co-culture or irrelevant antibodies with the same isotypes. Values are means $\pm \mathrm{SE}$; Con, untreated control; Veh, antibody vehicle control; *, significantly different from the relevant isotype control $(p<0.05, n=4)$.

$(p<0.05, n=4)$ when present for the $20 \mathrm{~h}$ co-culture period (20 h treatment) (Fig. 3a). All three concentrations of IL-1 $\beta$ were without effect, compared to the vehicle control, when added to the ASMC $24 \mathrm{~h}$ prior to the addition of the eosinophils and left there for the $20 \mathrm{~h}$ co-culture period ( $44 \mathrm{~h}$ treatment) (Fig. 3a).

In contrast to these observations, TNF- $\alpha$ increased eosinophil attachment to ASMC with either protocol (20 or $44 \mathrm{~h}$ treatment). TNF- $\alpha, 0.1 \mathrm{nM}$ and $10 \mathrm{nM}$, added for the $20 \mathrm{~h}$ co-culture period, significantly $(p<0.05, n=3)$ increased eosinophil attachment to $128.1 \pm 14.2 \%$ and $139.8 \pm 4.0 \%$ of the untreated control compared with $92.4 \pm 6.2 \%$ in the vehicle control but these increases were not significantly different (Fig. 3b). TNF- $\alpha, 1.0$ and $10 \mathrm{nM}$, when added to the ASMC $24 \mathrm{~h}$ prior to the $20 \mathrm{~h}$ co-culture period $(44 \mathrm{~h}$ treatment), also significantly $(p<0.05, n=3)$ increased eosinophil attachment in a concentration-dependent manner ( 0.1 vs $1.0 \mathrm{nM}$ and 1.0 vs $10 \mathrm{nM} p<0.05, n=3$ ) a)

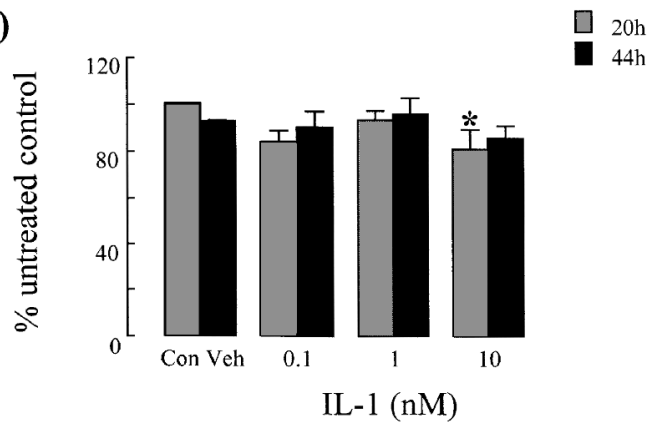

b)

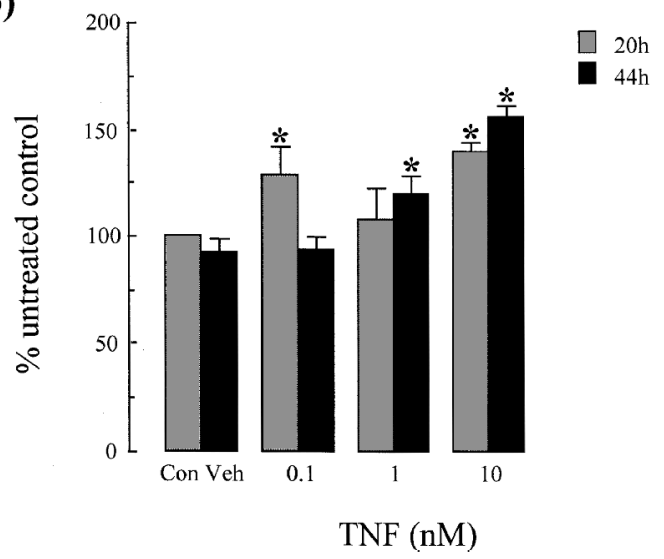

FIG. 3. The effect of: (a) IL-1 $\beta$ and (b) TNF- $\alpha$ on eosinophil adhesion to airway smooth muscle cells after $20 \mathrm{~h}$ of coculture. Values are means $\pm \mathrm{SE}$; Con, untreated control; Veh, cytokine vehicle control; *, significantly different from cytokine vehicle control $(p<0.05, n=4)$.

to $119.6 \pm 9.1 \%$ and $156.5 \pm 5.2 \%$ of control respectively (Fig. 3b).

TNF- $\alpha$ increased eosinophil attachment to ASMC when the co-culture period was shortened to $2 \mathrm{~h}$. TNF- $\alpha(10 \mathrm{nM})$ added $24 \mathrm{~h}$ before the $2 \mathrm{~h}$ co-culture period was started (26h treatment), significantly $(p<0.05, n=4)$ increased eosinophil attachment to $148.9 \pm 13.2 \%$ of the untreated control, whereas IL- $1 \beta$ was without effect $(112.3 \pm 12.2 \%, n=4)$. Neither $10 \mathrm{nM}$ TNF- $\alpha$, nor $10 \mathrm{nM}$ IL- $1 \beta$, had an effect when added for the co-culture period only $(117 \pm 10.9 \%$ and $91 \pm 9.7 \%$ of untreated control respectively, $n=4)$.

IL-1 $\beta(10 \mathrm{nM})$ did not modulate the increase in eosinophil attachment to ASMC induced by the $26 \mathrm{~h}$ treatment with $10 \mathrm{nM}$ TNF- $\alpha$. It had no effect, whether added with the TNF- $\alpha$ ( $26 \mathrm{~h}$ treatment) or only for the $2 \mathrm{~h}$ co-culture period (data not shown).

$I L-5$.

IL-5 did not modulate eosinophil attachment to ASMC under the various conditions tested. IL-5 (10 and $100 \mathrm{ng} / \mathrm{ml}$ ) added at the same time as the eosinophils, had no significant effect on eosinophil attachment to ASMC following $20 \mathrm{~h}$ of co-culture $(101.0 \pm 17.6 \%$ and $91.9 \pm 10.6 \%$ respectively, $n=3$ ) (Fig.4a). It was also without effect when the co-culture period was 
a)

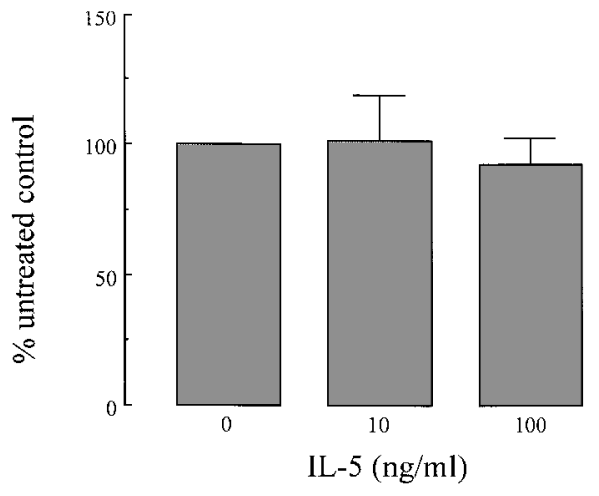

b)

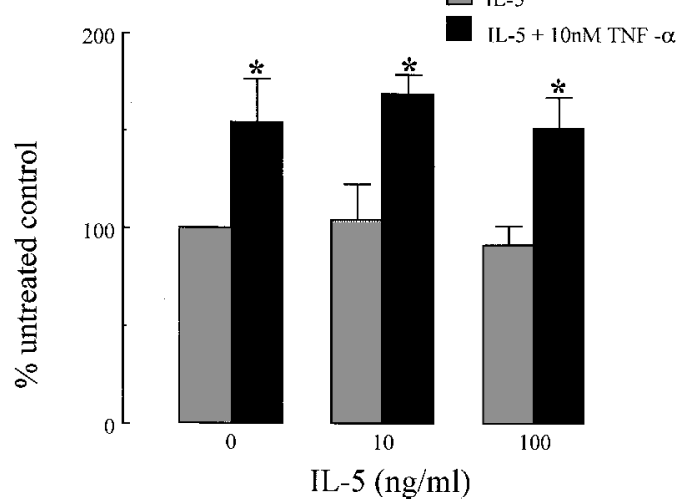

FIG. 4. The effect of IL-5 on eosinophil adhesion to airway smooth muscle cells: (a) after $20 \mathrm{~h}$ of co-culture, and (b) $2 \mathrm{~h}$ of co-culture alone and in combination with $10 \mathrm{nM}$ TNF-a added to the smooth muscle cells $24 \mathrm{~h}$ previously. Values are means $\pm \mathrm{SE}$; Con, untreated control; ${ }^{*}$, significantly different from untreated control $(p<0.05, n=4)$.

shortened to $2 \mathrm{~h}$ (Fig. $4 \mathrm{~b}$ ). There was also no added effect of IL-5 under conditions where TNF- $\alpha$ increased eosinophil attachment (Fig. 4b).

\section{Discussion}

In this study we demonstrate for the first time that human eosinophils can rapidly attach to human airway smooth muscle cells. Maximum numbers of attached eosinophils were observed after around $2 \mathrm{~h}$, with numbers falling to half that level by $20 \mathrm{~h}$ of coculture. Eosinophil attachment to ASMC at $2 \mathrm{~h}$ was significantly reduced in the presence of an antibody to the adhesion molecule VCAM- 1 , while at $20 \mathrm{~h}$ it was significantly reduced in the presence of an antibody to ICAM-1. The pro-inflammatory cytokine TNF- $\alpha$ significantly increased the number of attached eosinophils, whereas IL-1 $\beta$ and IL-5 were without effect.

Eosinophils have been shown to attach very rapidly to endothelial cells, reaching maximum numbers after 5 min of co-culture. ${ }^{14}$ They also adhere quickly to epithelial cells with co-culture periods of $30-60 \mathrm{~min}$ commonly being used. ${ }^{15,16}$ We hypothesized that eosinophils would also adhere rapidly to ASMC and found that maximum numbers were reached in the first $2 \mathrm{~h}$ and that substantial numbers were still attached after $20 \mathrm{~h}$ of co-culture. It would appear from our observations, compared with those of Munoz and colleagues,${ }^{14}$ that eosinophils attach more slowly to ASMC than they do to endothelial cells, as attached eosinophil numbers were only around $50 \%$ of maximum after $30 \mathrm{~min}$.

We investigated whether the adhesion molecules ICAM-1 and VCAM-1 were involved in eosinophil adhesion to ASMC because they are both constitutively expressed on ASMC and have been shown to participate in the attachment of activated lymphocytes to ASMC. ${ }^{1}$ ICAM-1 and VCAM-1 both play important roles in eosinophil adhesion to and transmigration through vascular endothelium. ${ }^{17}$ Interestingly, although ICAM-1 is expressed on epithelial cells, only eosinophils activated with C5a, PMA or eotax in (but not RANTES, MIP-1 $\alpha$, FMLP, $\mathrm{LTB}_{4}$, or PAF - activated cells) adhere in an ICAM-1 dependent manner. ${ }^{15,16,18}$ Our in vitro data are consistent with the hypothesis that VCAM-1 is important in the initial adhesion to ASMC, as antibodies to it significantly reduced the number of attached eosinophils at $2 \mathrm{~h}$, but not at $20 \mathrm{~h}$. They are also consistent with the hypothesis that ICAM-1 is involved in prolonged eosinophil adhesion to ASMC, as an antibody to ICAM-1 significantly reduced attached eosinophil numbers after $20 \mathrm{~h}$ of coculture. How ever, neither of the antibodies inhibited eosinophil attachment by more than $28 \%$, so other molecules must also be involved in both the initial phase and during prolonged adhesion.

Elevated levels of cytokines TNF- $\alpha$ and IL- $1 \beta$ have been found in the airways of asthmatic subjects. ${ }^{19,20}$ Macrophages, other immune cells and epithelial cells all produce TNF- $\alpha$. However, mast cells not only synthesize TNF- $\alpha$, but also store it in their granules and so are able to release it immediately following exposure to antigen. ${ }^{20}$ Interestingly, in the airways, mast cell numbers are highest in the smooth muscle layer. ${ }^{21}$ IL-1 $\beta$ is also produced by a wide range of immune and structural cells but the main source following antigen exposure is the macrophage. ${ }^{22}$

The cytokines TNF- $\alpha$ and IL-1 $\beta$ have been show n to affect many ASMC functions. IL-1 $\beta$ potentiated proliferation of guinea-pig ASMC ${ }^{10}$ and TNF- $\alpha$ stimulated human ASMC proliferation at low concentrations and was inhibitory at higher concentrations. ${ }^{9}$ These cytokines also stimulated ASMC secretion of a variety of other cytokines and chemokines, including some like GM-CSF, eotax in and RANTES (regulated on activation normal T-cells expressed and secreted), ${ }^{11,12,23}$ with direct effects on eosinophil recruitment, activation and viability. ${ }^{17}$ In addition, Lazaar and colleagues ${ }^{1}$ demonstrated that TNF- $\alpha$ and IL- $1 \beta$ also increased the cell surface expression of ICAM-1 and VCAM-1 on human ASMC. Most importantly they found that 
activated Tlymphocytes could then attach to the ASMC and induce ASMC proliferation. Thus ASMC are influenced by their inflammatory environment and may contribute further to the inflammation, regulating it locally and attracting more inflammatory cells to the muscle layer.

An additional finding of this study was that TNF- $\alpha$ also increases the adhesion of human eosinophils to human ASMC. TNF- $\alpha, 10 \mathrm{nM}$, increased the number of eosinophils attaching during the first $2 \mathrm{~h}$ of co-culture only if the ASMC had been treated with it for $24 \mathrm{~h}$ prior to the addition of the eosinophils, whereas with an extended co-culture period $(20 \mathrm{~h})$, it always increased the number of adhesive cells whether or not the ASMC had been treated with it for $24 \mathrm{~h}$ before. When TNF- $\alpha(0.1-10 \mathrm{nM})$ was present for the extended co-culture period $(20 \mathrm{~h})$ only, it increased eosinophil adhesion period to the ASMC in a concentrationindependent manner. However, when a $24 \mathrm{~h}$ pretreatment period with TNF- $\alpha$ was also included ( $44 \mathrm{~h}$ treatment), eosinophil adhesion was increased in a concentration-dependent manner. This apparent difference in effects of TNF- $\alpha$ may be due to timerelated responses to differential recruitment of the p 55 and p75 TNF- $\alpha$ receptors on the ASMC and/or the eosinophils by the lower concentrations of TNF- $\alpha$. Prolonged treatment with TNF- $\alpha$ may increase adhesive eosinophil numbers by increasing ASMC adhesion molecule expression, as already demonstrated for lymphocyte adhesion to ASMC. ${ }^{1}$

IL-1 $\beta$, on the other hand, was without significant effect on eosinophil adhesion to the ASMC under all conditions, except when present for just the $20 \mathrm{~h}$ coculture period. In this instance only, it caused a slight (19\%) but significant reduction in the level of eosinophil adhesion. This lack of (or inhibitory) effect of IL- $1 \beta$ was unexpected as, like TNF- $\alpha$, IL- $1 \beta$ has been show $n$ to increase the expression of both VCAM1 and ICAM-1 on ASMC following a $24 \mathrm{~h}$ treatment period. ${ }^{1}$ However, unlike TNF- $\alpha$, IL-1 $\beta$ also induces ASMC to release $\mathrm{PGE}_{2}{ }^{24,25}$ Therefore, it is possible that $\mathrm{PGE}_{2}$ released during the IL-1 $\beta$ treatment period, might have altered the response(s) of either cell-type and so negated any direct effects of IL-1 $\beta$ that might otherw ise have led to increased eosinophil adhesion to the ASMC under the conditions reported here.

IL-5 was also without an effect on eosinophil adhesion to the ASMC in this study. The IL-5 used was biologically active as it increased eosinophil survival when cultured alone for $24 \mathrm{~h}$ by up to $27 \%$ (data not shown). As well as promoting eosinophil differentiation, growth, migration and survival, IL-5 has been shown to induce eosinophil morphological changes rapidly ${ }^{26}$ and to enhance eosinophil adhesion to immobilised ICAM-1 and VCAM- ${ }^{27}$ and to endothelial cells in an integrin-dependent $(\mathrm{CD} 11 / 18)$ manne $\mathrm{r}^{28}$ in vitro. Extracellular matrix proteins may also mediate eosinophil adhesion to ASMC as integrins bind to them and CD44, a molecule which binds to the matrix protein hyaluronate, plays an important role in lymphocyte adhesion to ASMC. ${ }^{1}$ However, despite increasing eosinophil surface expression of CD44 with a 24 h IL-5 treatment, Matsumoto et al. did not observe increased eosinophil adhesion to immobilised hyaluronate following IL-5 treatment. ${ }^{29}$ Under the conditions reported in this study, any IL-5 induced changes may not be of the nature required, or sufficient, to successfully increase eosinophil adhesion to ASMC, even when TNF- $\alpha$ does increase it.

Many studies have show $n$ that eosinophil mediator release is induced and modulated by interactions between eosinophil adhesion molecules and their counter-ligands or extracellular matrix proteins. ${ }^{30-34}$ Interestingly, ASMC production of some ex tracellular matrix proteins is increased following exposure to serum from an atopic asthmatic. ${ }^{35}$ Adherent eosinophils in the airway smooth muscle layer are therefore likely to release mediators. Once activated, eosinophils may produce an extensive range of cytokines and grow th factors, including IL- $1 \beta$, TNF- $\alpha$, PDGF, FGF, TGF- $\beta$, that have been implicated in modulating ASMC proliferation ${ }^{3,9,10}$ and/or mediator production. ${ }^{4,11,12}$ The effect on the muscle cells of eosinophil adhesion to them will vary, depending on the balance of the many inflammatory mediators present and the severity of the allergic response at the time.

TNF- $\alpha$ is likely to be present before and after eosinophils reach the smooth muscle layer of asthmatic airways and, of course, is likely to modulate eosinophil behaviour, as well as that of the ASMC, and so regulate their interaction. Studies in vitro have demonstrated that TNF- $\alpha$-treated eosinophils have enhanced survival, up-regulated surface ex pression of the activation marker $\mathrm{CD} 69,{ }^{36}$ increased adhesion to immobilised ICAM-1 and VCAM- $1,{ }^{27}$ as well as degranulation, leukotriene $\mathrm{C}_{4}$ and superoxide production. ${ }^{26,37,38}$ Granule proteins cause tissue damage in vitro and have been implicated in epithelial shedding in vivo. ${ }^{17}$ We observed increased eosinophil adhesion to ASMC with no sign of ASMC detachment or overt morphological damage with eosinophil exposures to TNF- $\alpha$ of 2 or $20 \mathrm{~h}$.

This is the first study of eosinophil adhesion to airway smooth muscle cells. We have shown that adhesion is rapid and can be prolonged. As we found it is partially mediated through ICAM-1 and VCAM- 1 , it is likely to result in eosinophil mediator release and altered airw ay smooth muscle responses. We have also demonstrated that the cytokine TNF- $\alpha$ increases eosinophil adhesion to the smooth muscle cells at concentrations that also induce airway smooth muscle to secrete other pro-inflammatory cytokines and chemokines. It is therefore possible that eosinophils and ASMC may regulate each other's responses and inflammation locally in asthmatic airways, contributing to the pathogenesis and symptoms of asthma. 
ACKNOWLEDGMENTS: We thank the blood donors and the Theatre and Pathology Staff of the following Sydney Hospitals: Royal Prince Alfred, Concord Repatriation Ge neral, Royal North Shore, St Vincent's and Strathfield Private. We acknowledge the collaborative effort of the cardiopulmonary transplant team at St Vincent's Hospital. This study was supported by the Ramaciotti Foundations and the National Health and Medical Research Council of Australia.

\section{References}

1. Lazaar A, Albeda SM, Pilewski JM, Brennan, B, Pure E, Panattierei R. T lymphocytes adhere to airway smooth muscle cells via integrins and CD44 and induce smooth muscle cell DNA synthesis. J Exp Med 1994; 180: 807-16.

2. Johnson PRA., Armour CL, Carey D, Black JL Heparin and $\mathrm{PGE}_{2}$ inhibit DNA synthesis in human airway smooth muscle cells in culture. $\mathrm{Am}$ Physiol 1995:269; Lung Cell Mol Physiol 13:L514-L9.

3. Hawker KM, Johnson PRA, Hughes JM, Black JL. Interleukin-4 inhibits mitogen-induced proliferation of human airway smooth muscle cells in culture. Am I Physiol 1998; 275; Lung Cell Mol Physiol 19: L469-77.

4. Barnes P. Pharmacology of airw ay smooth muscle. Am J Respir Crit Care Med 1998; 158: S123-32.

5. James AL, Carroll N. The relationship between inflammatory cells in the airw ay wall and the airw ay luman. Am J Respir Crit Ca re Med 1998; 157: A396.

6. Egan RW, Umland SP, Cuss FM, Chapman RW. Biology of in terle ukin-5 and its relevance to allergic disease. Allergy 1996; 51: 71-81.

7. Hallahan AR, Armour CL, Black JL. Products of neutrophils and eosinophils increase the responsiveness of human isolated bronchial tissue. Eur Respir J 1990; 3: 554-8.

8. Johnson PRA, Black JL, Armour CL Investigation of platelet activating factor induced contraction of human bronchus. Eur Respir J 1992; 5: $970-4$.

9. Stew art A, Tomlinson P, Fe rnandes D, Wilson J, Harris T. Tumour necrosis factor- $\alpha$ modulates mitogenic responses of human cultured airway smooth muscle. Am J Respir Cell Mol Biol 1995; 12: 110-9.

10. De S, Zelazny E, Souhrada J, Souhrada M. IL-1 $\beta$ and IL-6 induce hyperplasia and hypertrophy of cultured guinea-pig airway smooth muscle cells. J Appl Physiol 1995; 78: 1555-63.

11. Ghaffar O, Hamid Q, Renzi PM, Allakhverdi Z, Molet S, Hogg JC, Shore SA, Luster AD, Lamkhioued B. Constitutive and cytokine stimulated expression of eotaxin by human airway smooth muscle cells. $A m J$ Respir Crit Care Med 1999; 159: 1933-42.

12. Hallsw orth MP, Soh CPC, Twort CHC, Lee TH, Hirst S. Cultured human airway smooth muscle cells stimulated by IL-1 $\beta$ enhance eosinophil survival. Am J Respir Cell Mol Biol 1998; 19: 910-9.

13. Hansel TT, De-Vries IJ, Rihs S, Wandzilak M, Betz S, Blaser K, Walker C. An improved immunomagnetic procedure for the isolation of highly purified human blood eosinophils. J Immunol Methods 1991; 145: 105-10.

14. Munoz NM, Hamman KJ, Rabe KF, Sano H, Zhu X, Leff AR. Augmentation of eosinophil degranulation and $\mathrm{LTC}_{4}$ secretion by integrin-mediated endothelial cell adhesion. Am J Physiol 1999:277 (Lung Cell Mol Physio 21): L802-10.

15. Godding V, Stark JM, Sedgwick JB, Busse WB. Adhesion of activated eosinophils to respiratory epithelial cells is enhanced by tumour necrosis factor- $\boldsymbol{\alpha}$ and interleukin-1 $\beta$. Am J Respir Cell Mol Biol 1995; 13: $555-562$.

16. Sato M, Takizaw a H, Kohyama T, Ohtoshi T, Takafuji S, Kawasaki S, Tohma $\mathrm{S}$, Ishii A, Shoji S, Ito K. Eosinophil adhesion to human bronchial epithelial cells: regulation by cytokines. Int Arch Allergy Immunol 1997; 113: 203-205.

17. Se minario M-C, Gleich GJ. The role of eosinophils in the pathogenesis of asthma. Current Opinion Im munol 1994; 6: 860-864.

18. Burkegaffney A, Hellewell PG. A CD18/ICAM-1-dependent pathway mediates eosinophil adhesion to human bronchial epithelial cells. $\mathrm{Am} \mathrm{J}$ Respir Cell Mol Biol 1998; 19: 408-418.
19. Broide DH, Lotz M, Cuomo AJ, Coburn DA, Federman EC, Wasserman SI. Cytokines in symptomatic asthma airways. J Allergy Clin Im munology 1992; 89: $958-967$.

20. Shah A, Church MK, Holgate ST. Tumour necrosis factor alpha: a potential mediator of asthma. Clin Exp Allergy 1995; 25: 1038-1044.

21. Carroll NG, Mutavdzic S, James AL Mast cells and neurophils in the airway wall in asthma. Amer J Respir Crit Care Med 1998; 157: A873.

22. Platanias LC, Vogelzang NJ. Interleukin-1: biology, pathophysiology, and clinical prospects. Amer J Med 1990; 89: 621-629.

23. John M, Hirst SJ, Jose PJ, Robichaud A, Berkman N, Witt C, Twort CHC, Barnes PJ, Chung KF. Human airway smooth muscle cells express and release RANTES in response to Thelper 1 cytokines. J Im munol 1997; 158: $1841-1847$

24. Pang L, Knox AJ. Effect of interleukin-1 $\beta$, tumour necrosis factor- $\alpha$ and interferon- $\gamma$ on the induction of cyclo-oxygenase- 2 in cultured human airway smooth muscle cells. Br J Pharmocol 1997; 121: 579-587.

25. Vigano T, Habib A, Bonazzi A, Boraschi D, Lebret M, Cassina E, Maclouf J, Sala A, Folco G. Cyclo-oxygenase-2 and synthesis of $\mathrm{PGE}_{2}$ in human bronchial smooth muscle cells. Am J Respir Crit Care Med 1997; 155 $864-868$.

26. Zeck-Kapp G, Czech W, Kapp A. TNF- $\alpha$-induced activation of eosinophil oxidative metabolism and morphology - Comparison with IL-5. Exp Dermatol 1994; 3: 176-188.

27. Fattah D, Page KR, Bezbaruah S, Priest RC, Horgan CM, Solari R. A rapid activation assay for human eosinophils based on adhesion to immobilized ICAM-1, VCAM-1 and IgG. Cytokine 1996; 8: 248-259.

28. Walsh GM, Wardlaw AJ, Hartnell A, Sanderson CJ, Kay AB. Interleukin-5 enhances the in vitro adhesion of human eosinophils, but not neutrophils, in a le ucocyte integrin (CD11/CD18) - dependent manner. Int Arch Allergy Appl Im munol 1991; 94: 174-178.

29. Matsumoto K, Appiah-Pippim J, Schleimer RP, Bickel CA, Beck LA, Bochner BS. CD44 and CD69 represent different types of cell-surface activation markers for human eosinophils. Am J Respir Cell Mol Biol 1998; 18: $860-866$.

30. Chihara J, Yamaoto T, Kayaba H, Kakazu T, Kurachi D, Yamamoto J, Iw asa S, Iida K, Urayama O, KobayashiY. Degranulation of eosinophils mediated by intercellular adhesion molecule-1 and its ligands is involved in adhesion molecule expression on endothelial cells - selective induction of VCAM-1. I Allergy Clin Im munol 1999; 103: S452-456.

31. Nagata M, Sedgwick JB, Vrtis R, Busse WW. Endothelial cells upregulate eosinophil superoxide generation via VCAM-1 expression. Clin Exp Allergy 1999; 29: 550-561.

32. Higashimoto I, Chihara J, Kakazu T, Yamamoto T, Kurachi D, Nakajima S Adhesion to fibronectin augments eosinophil radical oxygen products. Int Arch Allergy Im munol 1995; 108 (suppl 1): 48-49.

33. Yoshida K, Suko M, Matsuzaki G, Sugiyama H, Okudaira H, Koji I. Effect of fibronectin on the production of leukotriene $\mathrm{C}_{4}$ by eosinophils. Int Arch Allergy Imm unol 1995; 108 (suppl 1): 50-51.

34. Kita H, Horie S, Gleich GJ. Ex tracellular matrix proteins attenuate activation and degranulation of stimulated eosinophils. J Im munol 1996 156: $1174-1181$

35. Johnson PRA, Undew rwood PA, Armour CL, Black JL. The effect of beclomethasone on atopic asthmatic serum induced production of extracellular proteins by human airway smooth muscle cells in culture. Am J Respir Crit Care Med 1999; 159: A401.

36. Luttman W, Matthiesen T, Matthys H, Virchow JC. Synergistic effects of interleukin 4 or in terleukin-13 and tumour necrosis factor- $\alpha$ on eosinophil activation in vitro. Am J Respir Cell Mol Biol 1999:20:470-480.

37. Horie S, Gleich GJ, Kita H. Cytokines directly induce degranulation and superoxide production from human eosinophils. J Allergy Clin Im $m u$ nol 1996; 98: 371-381.

38. Roubin R, Elsas PP, Fiers W, Dessein AJ. Recombinant human tumour necrosis factor (rTNF) 2 enhances leukotriene biosyn thesis in neutrophils and eosinophils stimulated with the $\mathrm{Ca}^{2+}$ ionophore A23187. Clin Exp Immunol 1987; 70: 484-490.

\section{Accepted 12 May 2000}




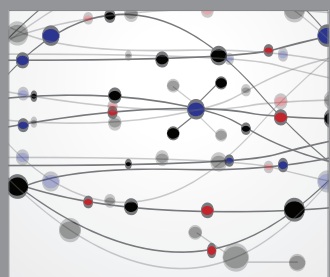

The Scientific World Journal
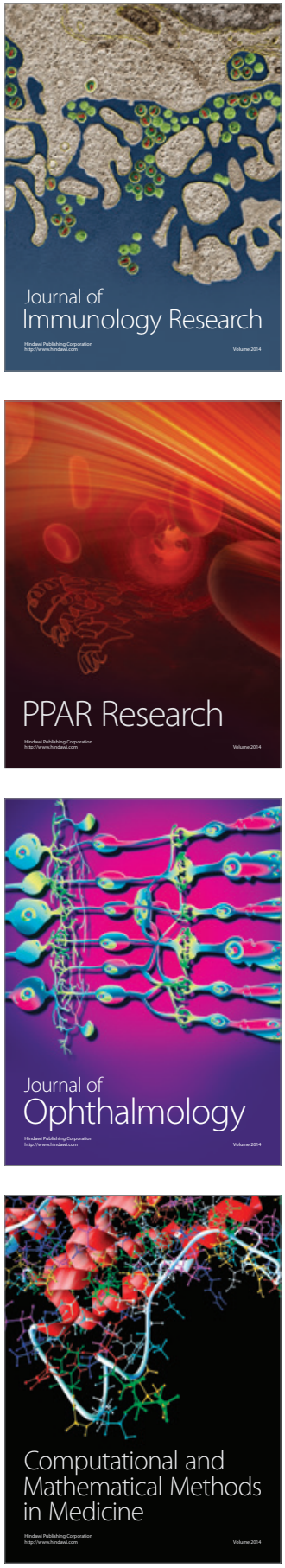

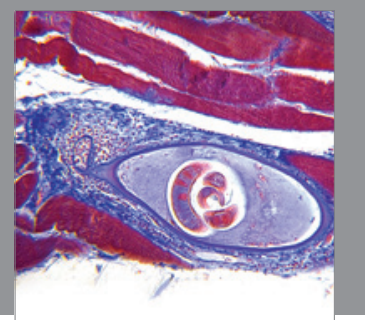

Gastroenterology

Research and Practice
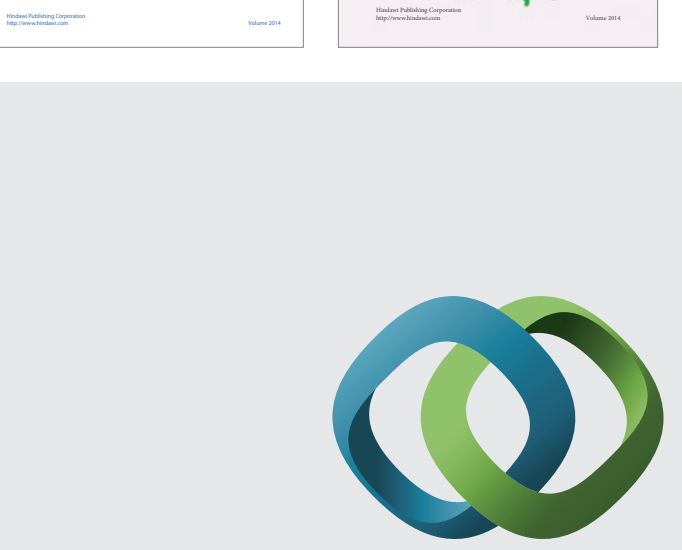

\section{Hindawi}

Submit your manuscripts at

http://www.hindawi.com
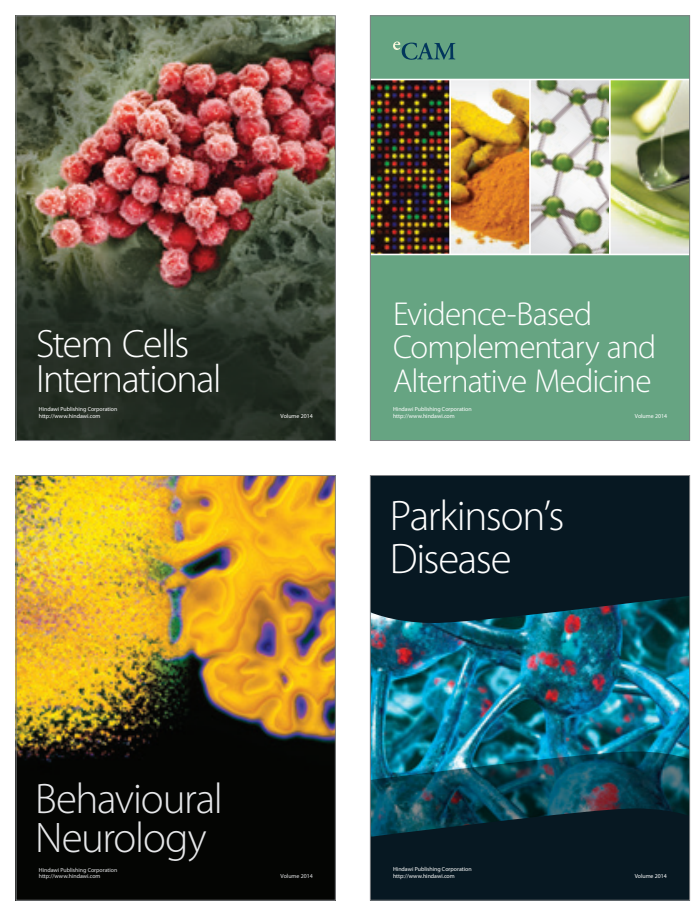

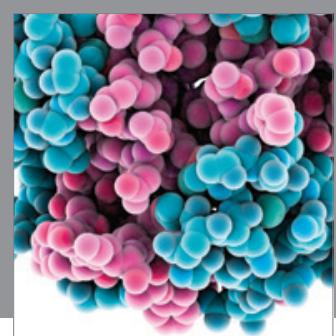

Journal of
Diabetes Research

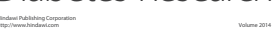

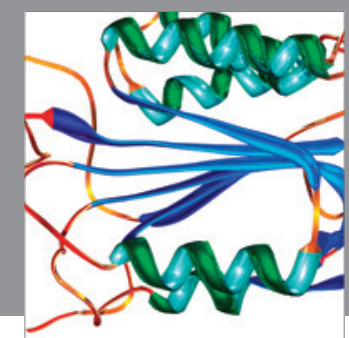

Disease Markers
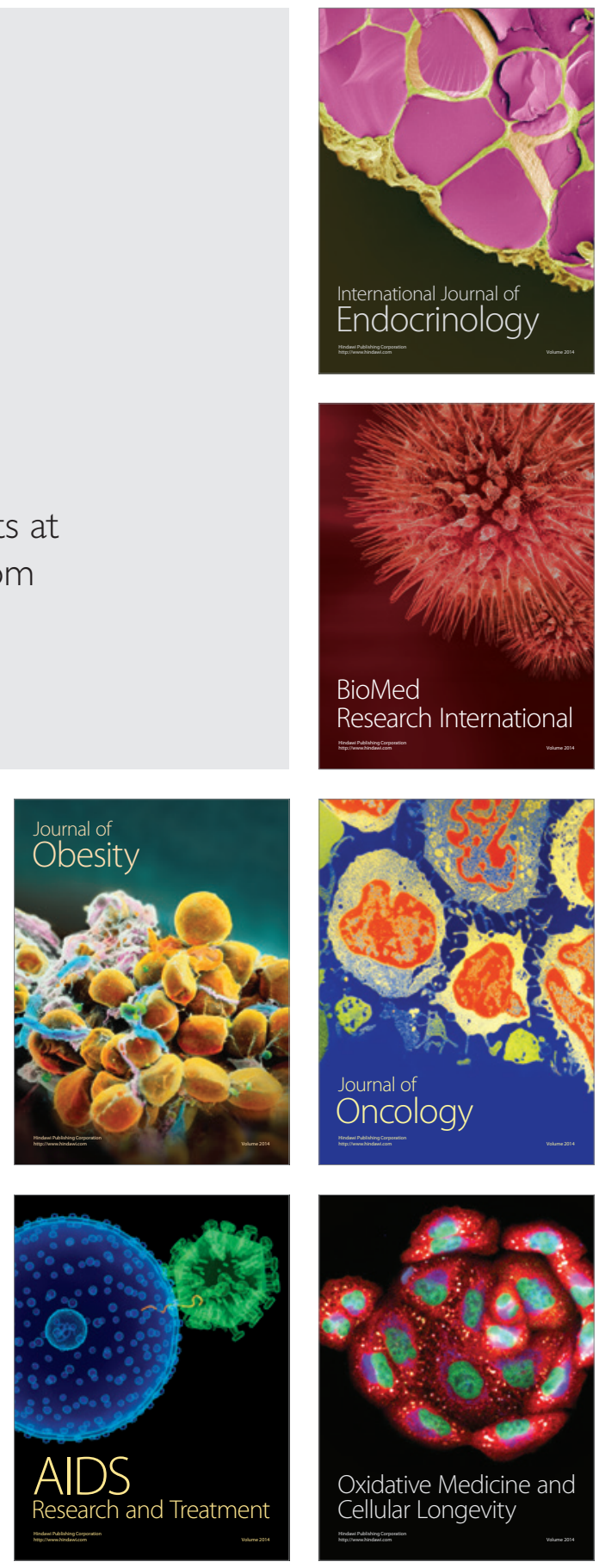